\title{
West Nile Virus Infection in Human and Animals: Potential Risks in Malaysia
}

(Jangkitan Virus Nil Barat pada Manusia dan Haiwan: Potensi Risiko di Malaysia)

\author{
Nur Ain NAJWA MOHD YUSERI, NOR YASMin AbD. RAHAMAN*,ABDUl RAHMAN OMAR, \\ SITI SURI ARSHAD, JALILA ABU \& HUSSNI OMAR MOHAMMED
}

\begin{abstract}
West Nile virus (WNV) is a zoonotic RNA virus maintained in enzootic cycles involving mosquito mainly Culex and Aedes spp. as the vector and birds as the reservoir host. WNV is endemic in Africa, Europe and Western Asia. Human infection results in asymptomatic illness such as fever, headache, tiredness, body aches, nausea, vomiting, skin rash, swollen lymph glands and neuroinvasive disease are seen in less than $1 \%$ of infected persons. The spectrum of symptoms in animals includes fever, weakness and paralysis of hind limbs, impaired vision, ataxia, head pressing, aimless wandering, seizures, inability to swallow, walking in circles and coma. Based on the previous study in Malaysia, the antibody and nucleic acid against $W N V$ were detected in Orang Asli, captive birds and horses. In this paper, potential risk factors contributing to WNV occurrence are discussed. How the disease or infection is diagnosed and controlled was also discussed.
\end{abstract}

Keywords: Arthropod-borne virus; vector; West Nile virus; zoonotic

\section{ABSTRAK}

Virus Nil Barat (WNV) adalah virus RNA zoonosis yang dikekalkan dalam kitaran enzootik yang melibatkan nyamuk terutamanya Culex dan Aedes spp. sebagai vektor dan burung sebagai perumah reservoir. WNV adalah endemik di Afrika, Eropah dan Asia Barat. Jangkitan pada manusia akan mengakibatkan penyakit tidak bergejala seperti demam, sakit kepala, keletihan, sakit badan, loya, muntah, ruam kulit, bengkak kelenjar limfa dan penyakit neuroinvasif dilihat kurang daripada 1\% pada orang yang dijangkiti. Spektrum simptom pada haiwan termasuk demam, lemah dan lumpuh anggota belakang, gangguan penglihatan, ataksia, tekanan kepala, merayau tanpa tujuan, kejang, ketidakupayaan untuk menelan, berjalan dalam lingkaran dan koma. Berdasarkan kajian terdahulu di Malaysia, antibodi dan asid nukleik terhadap WNV dikesan pada Orang Asli, burung sangkar dan kuda. Dalam kertas ini, faktor risiko berpotensi yang menyumbang kepada terjadinya WNV dibincangkan. Bagaimana penyakit atau jangkitan didiagnosis dan dikawal juga turut dibincangkan.

Kata kunci: Vektor; virus bawaan artopod; virus Nil Barat; zoonosis

\section{INTRODUCTION}

West Nile virus (WNV) is a zoonotic RNA virus from genus of Flavivirus in the family of Flaviviridae in which Japanese encephalitis virus (JEV), St. Louis encephalitis virus (SLEV), Zika, dengue fever and yellow fever are grouped (Morales et al. 2017). All of these viruses are categorised as arthropod-borne virus called arbovirus (Lynne 2016). Flavivirus is consisted of more than 70 recognized viruses (Yan-Jang et al. 2014). WNV virions are spherical in shape with a diameter of $50 \mathrm{~nm}$ and composed of enveloped positive single-stranded virus where the size of the genome is between 11000 and 12 000 nucleotides long with icosahedral capsid (Lynne 2016).

This virus is generally circulated across Africa, the Middle East, Asia, Southern Europe, Western Russia, America and Australia (KUNV sub-type of WNV). Asia is recognized as the region in which the virus is endemic (Trevejo \& Eidson 2008). The genome of WNV encodes 7 non-structural proteins, which are non-structural 1 (NS1),
NS2A, NS2B, NS3, NS4A, NS4B and NS5; 3 structural proteins that comprise of the capsid (c), pre-membrane (prM) and envelope (E) (Elseginy et al. 2014). The nonstructural proteins have many various purposes as the virus has a very limited number of proteins and they should provide numerous functions during infection. The structural proteins are encoded at the 5' end of the RNA strand and provide the purpose for virus entry and encapsulation of the genome.

WNV has two types of transmission cycles which are primary enzootic cycles involving vector and host and a second cycle involving potentially different arthropod and transmission to other hosts such as humans and horses. WNV transmission normally involves birds as reservoir host and mosquitoes as the vector. Bird-feeding argasid (soft) or amblyommine (hard) ticks are considered as the substitute vectors and can form bird-tick cycles in dry and also warm habitats (Dupraz et al. 2017). Migratory birds usually carry the virus and spread it to people by mosquitoes and ticks. 
There is no report on the transmission of WNV from human to human, but it can be transmitted to human via many modes such as organ transplantation, blood transfusion and breastfeeding (Blitvich 2008). Horses have been considered as the dead-end host because they usually produce insufficient viremia that makes them unable to be transferred to mosquitoes and there is no evidence that they can transmit WNV to human (Elisa et al. 2014).

As this virus can infect a wide range of vertebrates and arthropods and be transmitted with the aid of mosquitoes, it is one of the reasons why the virus has successfully circulated over a wide geographical area (Blitvich 2008). Malaysia is one of the Asian countries that are vulnerable to WNV infection. The temperate, tropical country coupled with the rainy condition is favorable for the breeding of the mosquitoes that have a major responsibility in WNV transmission. However, data on the life cycle of the perpetuation of the virus in endemic foci in Malaysia are lacking. Therefore, this paper will review important aspects of the lineage, detection, risk factors and preventive measures relevant to Malaysia.

\section{LINEAGE OF WNV}

WNV aligns into 7 lineages on the basis of nucleic acid homology with the dominant lineages deviating by the nucleotide differences with $25 \%$ to $30 \%$ (Richter et al. 2017). Lineage $1 \mathrm{WNV}$ has a worldwide circulation including Africa, Europe, Australia, Asia, North, Central America and the Middle East while lineage 2 is limited to Africa which infrequently progressing to severe disease and can cause mild febrile illness in human (Pattan et al. 2009). Lineage 1 can be divided into 3 sub-lineages; first is discovered from the Western Hemisphere, Africa, Middle East and Europe that constitutes lineage 1a, Kunjin virus (KUNV) from Australia serve as lineage $1 \mathrm{~b}$ and lineage $1 \mathrm{c}$ is composed of the virus from India (Bondre et al. 2007). Now, lineages 1 and 2 are endemic in southeastern Europe.

Lineage 3 was first reported close to the Czech Republic and Austrian border in 1997 which indicated the Rabensburg virus and this virus named after the first report of the infected Culex pipiens mosquitoes nearby Austrian town (Bakonyi et al. 2005). On the other hand, lineage 4 was first reported in the Caucasus Mountains in Russia from a Dermacentor marginatus tick (Lvov et al. 2004) meanwhile a group of human and mosquito was isolated for lineage 5 and this virus spreads in India since the early 1950 s and its cluster form sub-lineage $1 \mathrm{c}$ (Bondre et al. 2007). Lineage 6 discovered from Culex pipiens mosquitoes in Southern Spain in 2006 and this strain exactly associated with lineage 4 and the same strain with KUNV in Sarawak (Vazquez et al. 2010). The first reported of WNV strain in Senegal is Koutango virus that currently identified as different species but can serve as lineage 7 (Pesko \& Ebel 2012). As the human infection is not reported in lineage 4 , lineage 6 and lineage 7 , the human pathogenicity is poorly understood.

\section{HISTORY AND PREVALENCE OF WNV}

The prevalence of WNV was highly associated with animals and people who lived in the west and those who commonly live in temperate and tropical regions around the world. In addition, West Nile disease (WND) is the disease caused by WNV, a neurotropic human pathogen that is the causative agent of West Nile fever (WNF) and encephalitis. More than 2.5 million people have WND over 12,000 reported cases of encephalitis from 1999 to 2010 and over 1300 deaths were recorded (Kilpatrick 2011). Furthermore, CDC reported the first case of WND in the Western Hemisphere occurring in an exotic zoo on birds, crows and horses. The first discovered of WNV is in 1937 in the West Nile District of Uganda from the blood of a febrile woman (Sambri et al. 2013) while equine encephalitis caused by WNV was first isolated in the early 1960's in Egypt and France (Murgue et al. 2001).

The human outbreaks were generally related with mild febrile illnesses infrequently reported in Israel and Africa until the early 1990's (Petersen et al. 2013). In parts of Russia, Southern and Eastern Europe, the new viral strains that were similar to the African strain caused increased outbreaks (Sambri et al. 2013). In 1996, the first large outbreak occurred in Romania with 4.1\% (16 out of 393) of WNV antibody detected in human (Blitvich 2008). During the late summer of 1999, WND was entered into the Western Hemisphere when people infected with WNV were diagnosed in New York State (Marfin \& Gubler 2001). According to the CDC, WND was first isolated in the United States in 1999 with 7 deaths and 62 cases (12\% case fatality rate) in New York City and surrounding countries. A total of $65 \%$ from all 2774 human cases of non-neuroinvasive occurred in 1999 in the United States (Trevejo \& Eidson 2008).

In the United States, $97 \%$ of 1121 of non-human mammal cases occurred in 1999 (Reisen 2013). Meanwhile, in North America, the New York 1999 (NY99) strain of WNV was first discovered in dead American crow (Komar et al. 2003). For avian species, $80 \%$ from 4106 dead bird cases that include crows, jays and magpies obtained in 1999 in the United States. In the summer of 2001 in Illinois, WNV was first isolated after a laboratory analysis verified that two dead crows found in Cook County had died because of this virus. Meanwhile, nucleic acid of WNV was detected in snakes in Pennsylvania in 2003 with 59\% (2 out of 123) in the Eastern Garter snake species (Dahlin et al. 2016). Between 2004 and 2005, 65\% of the 76 Californian cases that involved fox squirrels, as well as western and eastern gray squirrels resulted in death (Padgett et al. 2007).

Meanwhile, in China, $15 \%$ of 309 cases from the cat species were tested positive to WNV infection while another 5\% were from 367 cases that occurred in the dog species in 2010 (Lan et al. 2011). The recent outbreak was in 2010 which was also the second largest outbreak in human cases that occurred in Greece with $75 \%$ having symptoms and $13 \%$ fatalities from 262 cases (Chancey et al. 2015). Infected cases in India in 2015 saw a high 
percentage of $45 \%$ from 209 duck cases in the state of Kerala and a shocking $97 \%$ of 40 cases in the Kottayam district were tested positive in addition to $34 \%$ of 153 cases in Alapphuza (Kalaiyarasu et al. 2016).

\section{WNV DETECTION IN MALAYSIA}

To date, there is no WNV outbreak reported in Malaysia. The seropositivity of WNV was reported in the Orang Asli and captive birds meanwhile the detection of WNV antigen was only reported in horses. According to these studies, no WNV infections were reported in other populations except in those population stated. Besides WNV, KUNV (sub-type of WNV) was also detected in Sarawak (Ching et al. 1970). Data on the epidemiology of WNV in Malaysia are scarce and to implement cost-effective control and eradication, more data are needed.

Kunjin Virus (KUNV) The Kunjin virus is a sub-type of WNV that is endemic to Oceania, Australia (CDC 2000). KUNV was detected in mosquito populations from different areas in Sarawak including the coastal district near Kuching, forest areas, around rivers and farms (Ching et al. 1970). Sarawak is the largest among 13 other states in Malaysia with the size almost equal to West Malaysia. The strains were recovered from the pool of $C$. pseudovishnui spp. in the inland area of Sarawak near the rice growing, pig and fowl breeding areas. The complement-fixation study with an anti-serum prepared against the strains demonstrated very close relation to WNV, JEV and KUNV. Although the cross-protection tests showed the type of strains were different from WNV, it was very closely related.

Orang Asli Populations According to Figure 1, a study reported the seroprevalence in the Orang Asli population is $1.21 \%$ (9 out of 742) located in 7 states in Peninsular Malaysia (Perak, Melaka, Pahang, Negeri Sembilan, Kelantan, Selangor and Johor) between September 2012 and February 2013 (Marlina et al. 2014). Majority of the Orang Asli are forest dwellers which their serum samples were used to estimate the seroprevalence with the WNV IgG enzyme-linked immunosorbent assay (ELISA) method. The test for anti-dengue and anti-tick-borne encephalitis virus IgG ELISA were determined to rule out cross-reactivity. The highest percentage for the seroprevalence of WNV was in Pahang. The age was associated with the seropositive anti-WNV IgG but not with gender. In this study, those aged under 16 years old have the highest seroprevalence towards WNV.

Captive Birds The study in Malaysia according to Figure 1 was reported that the seroprevalence in captive birds is $4.41 \%$ (3 out of 68 ) in 4 different locations in Selangor between November and December 2010 (Rais et al. 2011). The first location was Tanjung Kajang, where the birds belong to the farmer as biological control in the paddy field area; the Faculty of Veterinary Medicine, Universiti Putra Malaysia (UPM) where the birds belong to a private owner who came for treatment; and the other two locations were the National Zoo and Sunway's Wildlife Park used for recreational activities. The serum samples were subjected to the competitive ELISA (c-ELISA) against WNV prE in captive birds.

Horses A total of 7 out of 20 were detected positive for the WNV antigen in 3 selected areas in the central part of Malaysia that consists of Mont Kiara, Cheras and Perbadanan Putrajaya (Figure 1) (Sifa et al. 2018). For the antigen detection, nasopharyngeal swabs from the horses were tested using RT-PCR. The species of the horses involved were warmbloods and thoroughbreds. The positive results from RT-PCR assay were sent for DNA sequencing for virus confirmation.

\section{CLINICAL SIGNS OF WNV}

As stated earlier, no WNV outbreak in Malaysia was reported until now. However, this virus could spread in Malaysia because the mosquito acts as the main vector. Malaysians should be aware of the possible clinical signs of

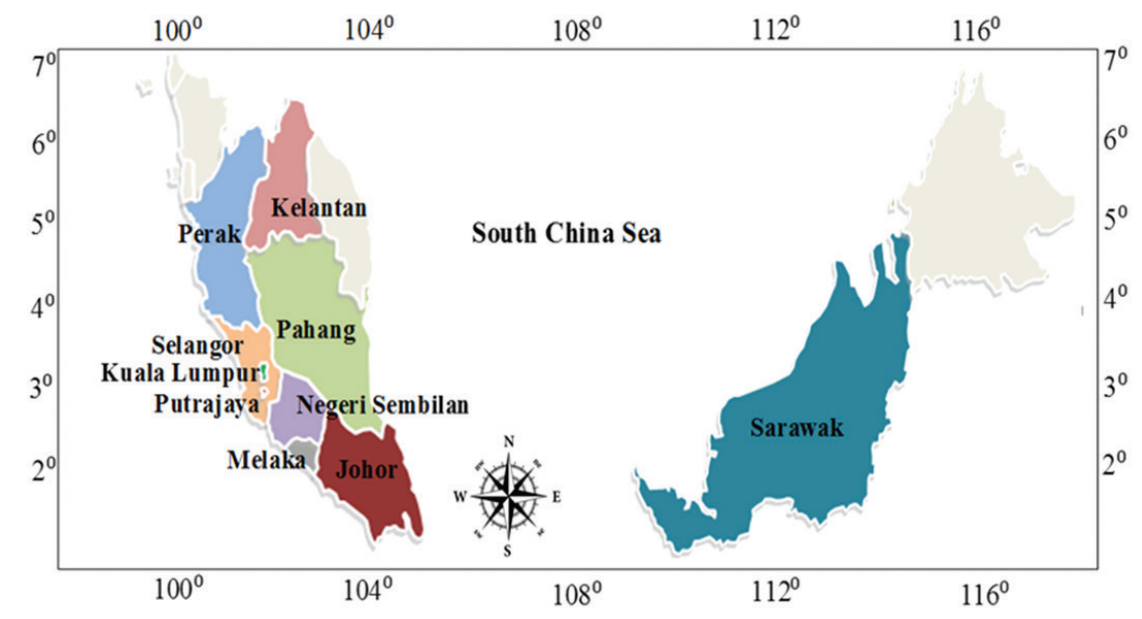

FIGURE 1. Map of Malaysia showing the WNV infection area. The color indicates: Orang Asli Captive birds Horses KUNV 
WNV and precautions should be taken based on the clinical signs to avoid the spread of WNV. The summarization of the clinical signs based on geographical area and host can be seen in Table 1. WNV produces 3 different clinical effects on humans that can be categorized into asymptomatic infection, temperate fever or West Nile fever (WNF) and neuroinvasive disease or West Nile encephalitis (Petersen et al. 2013).

The symptoms like fever, headache, chills, diaphoresis (excessive sweating), weakness, lymphadenopathy (swollen lymph nodes), drowsiness and pain in the joints will only be apparent after the febrile stage of two to eight days of incubation period (Hayes et al. 2005). WNV infection in the bird is characterised by neurologic signs such as ataxia, incoordination and paralysis while nonneurologic signs include depression, ruffled feathers and weight loss (van der Meulen et al. 2005). Birds infected with WNV always die in the first $24 \mathrm{~h}$ from the onset of the clinical signs (Blitvich 2008). Besides, lesions in the most infected tissues such as brain, liver, heart, kidney and spleen occurred in infected birds (Steele et al. 2000).

WNV has been incriminated in extensive morbidity and mortality in horses under natural setting. Experimental infection studies done by the Centers for Disease Control and Prevention (CDC) showed that the most of WNV infections in horses are asymptomatic and clinical signs were observed in 1 out of $12(8 \%)$ animals (Bunning et al. 2002). Clinical signs such as incoordination, stumbling, weakness, muscle twitching, depression and fearfulness shown by infected horses (Blitvich 2008). Fever is not commonly observed while in severe cases, the horses become recumbent and the illness normally lasts for three weeks. Almost $80 \%$ of clinical signs of the infected horses that survive can fully recover. However, the risk of death can be reduced by almost $44 \%$ by vaccination (Ward et al. 2016).

\section{DIAGNOSIS OF WNV IN MALAYSIA}

Diagnosis of WNV is based on the history of exposure, clinical signs and the result of diagnostic tests. The presumption of the WNV disease in susceptible hosts is confirmed with laboratory tests (Ledermann et al. 2011). Because humans and horses have low-level of viremia as well as the late occurrence of clinical signs when the viremic phase is over, the serological tests are used to confirm exposure to WNV by detecting antibodies. The preferred rapid and efficient serological assays that do not require the use of infectious virus are enzyme-linked immunosorbent assay (ELISA) (Roehrig et al. 2003), hemagglutination-inhibition test (HIT) (Weingartl et al. 2003) and immunofluorescence assay (IFA) (Malan et al. 2003).

TABLE 1. Summary of clinical signs of WNV in human and animals

\begin{tabular}{|c|c|c|c|c|}
\hline \multicolumn{2}{|c|}{ Categories } & \multirow{2}{*}{$\begin{array}{l}\text { Clinical Signs } \\
\begin{array}{l}\text { Fever, headache, body aches, tiredness, joint pain, swollen lymph glands, } \\
\text { skin rash }\end{array}\end{array}$} & \multirow{2}{*}{$\begin{array}{l}\text { Geographical } \\
\text { Distribution } \\
\text { Cuyahoga County } \\
\text { United States }\end{array}$} & \multirow{2}{*}{$\begin{array}{l}\text { References } \\
\text { Appavu et al. (2015) } \\
\text { Lindsey et al. (2009) }\end{array}$} \\
\hline Human & Infant & & & \\
\hline & Adult & $\begin{array}{l}\text { Mild fever, headache, chills, diaphoresis weakness, lymphadenopathy, } \\
\text { drowsiness and pain in the joints }\end{array}$ & $\begin{array}{l}\text { Romania } \\
\text { United States } \\
\text { Greece }\end{array}$ & $\begin{array}{l}\text { Chancey et al. (2015) } \\
\text { Trevejo and Eidson (2008) }\end{array}$ \\
\hline & Elderly & $\begin{array}{l}\text { A headache, high fever, stiff neck, confusion, coma, tremors, convulsions } \\
\text { and muscle weakness. The worse part can cause encephalitis, meningitis } \\
\text { and acute flaccid paralysis }\end{array}$ & United States & Sejvar (2014) \\
\hline & $\begin{array}{l}\text { Pregnant } \\
\text { Woman }\end{array}$ & $\begin{array}{l}\text { Weakness, difficulty walking, fevers, chills, headaches, nuchal rigidity, } \\
\text { nausea, vomiting and loss of sensation }\end{array}$ & United States & Stewart (2013) \\
\hline \multirow[t]{9}{*}{ Animals } & Wild Bird & $\begin{array}{l}\text { Neurologic signs (ataxia, incoordination, and paralysis) while the non- } \\
\text { neurologic signs (depression, ruffle feathers and weight loss) }\end{array}$ & $\begin{array}{l}\text { United States } \\
\text { North America } \\
\text { Israel }\end{array}$ & $\begin{array}{l}\text { van der Meulen et al. (2005) } \\
\text { Blitvich (2008) } \\
\text { Komar et al. (2003) }\end{array}$ \\
\hline & $\begin{array}{l}\text { Domestic } \\
\text { Duck }\end{array}$ & $\begin{array}{l}\text { Botulism, degenerative, traumatic, infectious processes, recumbency to } \\
\text { leg and wing paralysis }\end{array}$ & $\begin{array}{l}\text { India } \\
\text { Canadian }\end{array}$ & $\begin{array}{l}\text { Kalaiyarasu et al. (2016) } \\
\text { Wojnarowicz et al. (2008) }\end{array}$ \\
\hline & Equine & $\begin{array}{l}\text { Incoordination, stumbling, weakness, muscle twitching, depression, and } \\
\text { fearfulness }\end{array}$ & $\begin{array}{l}\text { Egypt } \\
\text { France } \\
\text { Australia }\end{array}$ & $\begin{array}{l}\text { Bunning et al. (2002) } \\
\text { Murgue et al. (2001) }\end{array}$ \\
\hline & Bat & Weakness and paralysis & Louisiana & Davis et al. (2006) \\
\hline & Macaque & Scrotal edema, anorexia, weight loss, and weakness & & Ratterree et al. (2004) \\
\hline & Snake & Weakness and immobility & Pennsylvania & Dahlin et al. (2016) \\
\hline & Squirrel & Uncoordinated movement, paralysis, circling, lethargy and death & California & Padgett et al. (2007) \\
\hline & Cat & Show mild nonspecific signs including lethargy and loss of appetite & China & \\
\hline & Dog & No clinical signs & & Lan et al. (2011) \\
\hline
\end{tabular}

Notes: Infant $=$ Child under a year old; Elderly $=$ Person over the age 65 
Due to potential of cross-reactions among other Flavivirus observed in these serological tests, the seropositivity has to be interpreted carefully (Roehrig et al. 2003). It has been suggested that the specificity of the serological results must be confirmed using virus neutralization tests (VNT) that use a panel of virus known to spread in the area under investigation (Dauphin \& Zientara 2007). In addition, the advantages of VNT are to measure the titer needed to block the cytopathic effects (CPE) of the virus besides its high sensitivity and specificity.

In Malaysia, the summarization of the diagnosis for WNV is tabulated in Table 2. According to Orang Asli and captive birds, there were only detected by using a serological method. Meanwhile, for the horses, there were detected by using molecular method. Serology method was tested using ELISA while for the molecular method was tested using RT-PCR then, the positive results for RTPCR were further sent for virus confirmation (Sanger DNA sequencing).

\section{CONTROL MEASURES AND PREVENTION OF WNV IN MALAYSIA}

Since there is no outbreak of WNV in Malaysia yet, no control or prevention of this virus is practiced. Due to the many possibilities that the virus could spread in Malaysia via a vector, the only precaution is focused on the mosquito control to prevent this virus from spreading widely.

Vaccination Recently, there are no vaccines for WNV in humans as human vaccination programs could not influence the viral amplification in nature because humans are incidental hosts for WNV disease. The equine vaccines have promising results from phases 1 and 2 on human vaccine candidates. However, phase 3 efficacy trials have not been attempted due to the unknown market demand and the potential of WNV vaccine and logistical difficulties in conducting phase 3 clinical trials for this widely dispersed disease (Beasley 2011). Preliminary analysis suggested that universal WNV vaccine coverage would not be costeffective. This vaccine can be used in Malaysia in the equine population to control the WNV from spreading.

Mosquito Control The best way to control the mosquito populations is avoiding outdoor activities during summer when mosquito activity is at its peak (dusk and dawn) and wearing shoes, socks, long pants and long-sleeved shirts during outdoor activities. The use of personal protection to avoid exposure to the mosquito is mainstay prevention. Additionally, mosquito repellant that contains diethyltoluamide or permethrin can be used on exposed skin and clothing can be sprayed with repellents as well as the need to eliminate standing water to prevent mosquitoes from breeding. Like dengue fever, the vector Aedes spp. is endemic in Malaysia, people use mosquito repellent to control the mosquito populations. This situation can also be used in controlling WNV infection as this virus also brought about vector-borne disease.

\section{POTENTIAL RISK FACTORS OF WNV IN MALAYSIA}

In Malaysia, many risk factors may lead to the WNV transmission in humans and also animals. The potential risk factors are the availability of wild birds, mosquito populations, geographical distribution, urban and sub-urban distribution, climate changes and also bat populations.

Availability of Migratory Birds According to Marlina et al. (2014), the risk factors related to the presence of WNV in Malaysia include migratory birds as the natural reservoir host. There is two migration period of birds which are the Northern and Southern Hemisphere bound. According to Bamford et al. (2008), the cycle of migration birds is categorised into four consisting of breeding time which is May to August, Southward migration time from August to November, non-breeding time from December to February, and Northward migration time from March to May. The west coast of Peninsular Malaysia and the eastern state of Sabah are the important locations where the migratory birds land. Besides that, Pulau Tengah, Johor and Kapar Energy Ventures, Selangor which located in the west coast of Peninsular Malaysia are known as the popular locations for the landing areas of migratory birds. Migratory birds that land at Kapar, Selangor have higher water bodies for the mosquitoes breeding (Kumar et al. 2018). Most of the shorebirds are the potential sources of Flavivirus including WNV and JEV. Those migratory birds can transmit the WNV via mosquito as the vector. Figure 2 shows the few species of wild birds that can transmit WNV during the migration period.

Mosquito Populations According to Marlina et al. (2014), one of the risk factors for WNV transmission is the availability of Culex spp. as the major vector. Mosquito is the main vector in the transmission of WNV. Vectors are

TABLE 2. Diagnosis of WNV in Malaysia

\begin{tabular}{lccc}
\hline Categories & Serology (ELISA) & Molecular (RT- PCR) & $\begin{array}{c}\text { Virus confirmation } \\
\text { (DNA Sequencing) }\end{array}$ \\
\hline Orang Asli & $\sqrt{ }$ & - & - \\
Captive birds & $\sqrt{ }$ & - & - \\
Horses & $\sqrt{ }$ & $\sqrt{ }$ & $\sqrt{ }$ \\
\hline
\end{tabular}

Notes: $\sqrt{ }=$ Applicable to the sample testing; - = Not applicable to the sample testing 


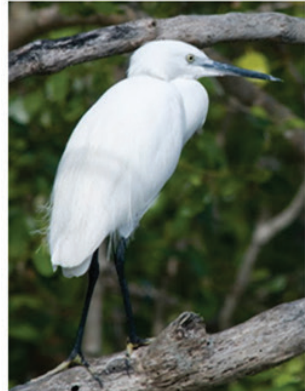

(a)

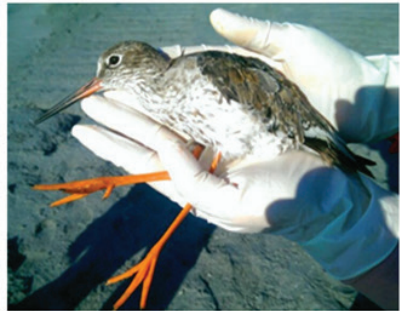

(e)

(b)
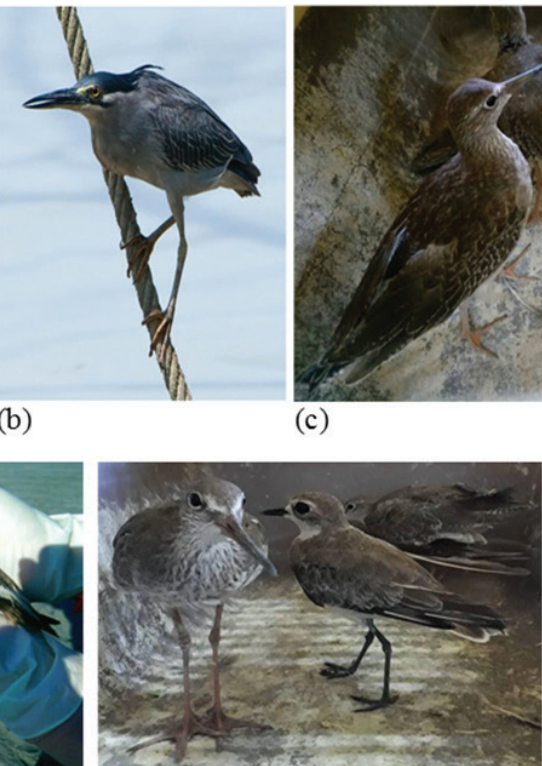

(f)

(c)
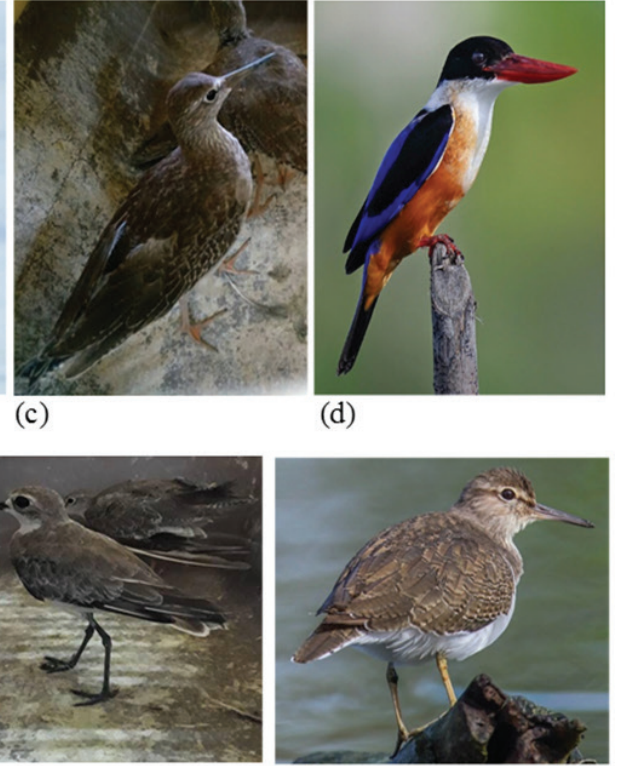

(g)

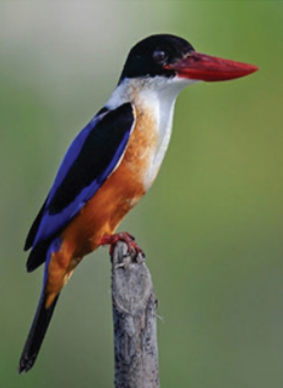

(d)

FIGURE 2. Migratory and resident wild birds' species in Malaysia. Note: Resident birds consist of (a): Little Egret, (b): Striated Heron; Migratory birds consist of (c): Greater Sand Plover, (d): Black-capped Kingfisher,

(e): Common Redshank, (f): Terek Sandpiper and Lesser Sand Plover, (g): Common Sandpiper

very important in arbovirus transmission and the absence of mosquito will prevent this transmission. WNV is spread by the Culex spp. including C.pipiens, C.quinquefasciatus, and $C$.tarsalis which are the primary mosquito vectors in the United States (Rizzoli et al. 2015). These mosquitoes typically feed on the evening to morning. In Malaysia, the abundance of Culex spp. is one of the potential risks of WNV transmission.

Geographical Distribution The geographical area in Malaysia like having palm cultivation, rubber cultivation and rice field cultivation can contribute to the WNV transmission. This is because all those areas are considered as the mosquito breeding sites. According to Kumar et al. (2018), rice field plantations are common areas for the mosquitoes to breed primarily the Culex and Anopheles spp. A previous study reported that paddy cultivation in the Republic of Korea is related to the mosquito populations (Richards et al.2010). In rubber plantation, the tree holes and latex-collection cups provide the breeding sites for the mosquito (Paily et al. 2013). Although no report on the Culex spp. in the area of rubber plantation in Malaysia (Kumar et al. 2018), the mosquito species are high in Thailand in the rubber plantations and forest areas. A study by Sumodan et al. (2005) state that Culex vishnui were found in the Kanchanaburi and Khon Kaen in rubber plantations area. Other than that, the Aegypti spp. is also found in oil palm monoculture and the highest abundance of Aedes spp., which is $60.9 \%$, was found in the polyculture in the rainforest in Southeastern Cote d'Ivoire (Zahouli et al. 2017). Aedes spp. is the vector for dengue fever. Therefore, this species could also be a vector for the WNV transmission because dengue fever was grouped in the same group with WNV.
Urban and Rural Areas The urbanisation process can increase mosquitoes breeding. This is because the urbanisation process can increase adult survival time and larval evolution which can increase the vector capacity, compared to the rural area. The transformation of the mosquito-breeding sites from the natural habitats to artificial habitats is known as an urbanisation process. The disposable containers and used tires are the examples of artificial habitat. In the United States, higher pupal and larval density reported in an urban area (Bartlett-Harley et al.2012). Thus, the higher capacity to support the larval evolution is in urban habitats as urban areas had fewer predators and less drift from agricultural insecticides ( $\mathrm{Li}$ et al. 2014).

Climates Changes Climate changes can also be a potential risk factor of WNV transmission because it will cause spreading of the arthropod-borne virus during the mosquito life cycle (Impoinvil et al. 2012). When the temperature is increased, the percentage of arthropod-borne infection in the mosquito is high and the incubation time decreased (Kumar et al. 2018). In Malaysia, the climate is tropical with the temperature between $20^{\circ} \mathrm{C}$ and $30^{\circ} \mathrm{C}$ throughout the year and have huge average rainfall, which is almost $2500 \mathrm{~mm}$ in Peninsular Malaysia thus, making this environment suitable for mosquito breeding conditions. Furthermore, the warm temperature climate in Malaysia is primarily associated with the transmission of WNV.

Bat Populations The next risk factor is bat populations in which bats are abundance in caves, trees, roofs in housing areas and close to the paddy field area (Kumar et al. 2018). These bats can transmit the WNV infection via 
the mosquito vector. According to Breed et al. (2006), the only bat that has the ability to cross between Peninsular Malaysia, Sumatra, and Australia to the New Guinea comes from the Pteropus spp. Therefore, the transmission of WNV can spread to Malaysia if bats with WNV infection cross to Malaysia. This transmission cycle can be categorized as mosquito-bat-mosquito transmission. An infected mosquito can also bite and pass the virus to other susceptible hosts.

\section{CONCLUSION}

In conclusion, current surveillance efforts should focus on the early detection of WNV activity in the Culex mosquito and migratory bird. This is due to the abundance of the Culex spp. in Malaysia and birds from other countries migrating to Malaysia during the migration season. Cooperation between veterinarians, physicians and public health personnel with the sharing of information will form an effective and timely population intervention. The observation of the prevalence rate of WNV in Malaysia is very important so that it can be used in the future to prevent this virus from widely spreading into the environment and among animal populations in Malaysia. Regardless of the growing knowledge of WNV, questions remain regarding the virus's vectors and reservoirs, pathogenesis, and genetic diversity. These questions highlight the need to optimize surveillance and public health intervention in case of WNV epidemic.

\section{ACKNOWLEDGEMENTS}

This review paper is based on work supported by Universiti Putra Malaysia under research grant UPM 700-2/1/GP-IPM/2016/9510500 and UPM 700-2/1/GPIPS/2017/9547800. The author reported no conflicts of interest in this work.

\section{REFERENCES}

Bakonyi, T., Hubalek, Z., Rudolf, I. \& Nowotny, N. 2005. Novel Flavivirus or new lineage of West Nile virus, Central Europe. Emerging Infectious Disease 11(2): 225-231.

Bamford, M., Watkins, D., Bancroft, W., Tischler, G. \& Wahl, J. 2008. Migratory Shorebirds of the East Asian-Australasian Flyway: Population Estimates and Internationally Important Sites. Wetlands International - Oceania. Canberra, Australia.

Bartlett-Harley, K., Unlu, I., Obenauer, P., Hughes., Healy, S., Crepeau, T., Farajollahi, A., Kesavaraju, B., Fonseca, D., Schoeler, G., Gaugler, R. \& Strickman, D. 2012. Larval mosquito habitat utilization and community dynamics of Aedes albopictus and Aedes japonicas (Diptera: Culicidae). Journal of Medical Entomology 49(4): 813-824.

Beasley, D. 2011. Vaccines and immunotherapeutic for the prevention and treatment of infections with West Nile virus. Immunotheraphy 3(2): 269-285.

Blitvich, B.J. 2008. Transmission dynamics and changing epidemiology of West Nile virus. Animal Health Research Reviews 9(1): 71-86.

Bondre, V.P., Jadi, R.S., Mishra, A.C., Yergolkar, P.N. \& Arankalle, V.A. 2007. West Nile virus isolates from India. Journal of General Virology 88(3): 875-884.
Breed,A.C., Smith, C.S. \& Epstein, J.H. 2006. Winged wanderers: Long distance movements of flying foxes. The Encyclopedia of Mammals, edited by Macdonald, D.W. Oxford: Oxford University Press. pp. 464-475.

Bunning, M.I., Bowen, R.A., Cropp, C.B., Sullivan, K.G., Davis, B.S., Kala, N., Godsey, M.S., Baker, D., Hettler, D.T., Holmes, D.A., Biggerstaff, B.J. \& Mitchell, C.J. 2002. Experimental infection of horses with West Nile virus. Emerging Infectious Disease 8(4): 380-386.

Centers for Disease Control and Prevention (CDC). 2000. Guidelines for surveillance, prevention, and control of West Nile virus infection - United States, 2000. Morbidity and Mortality Weekly Report 49(2): 25-28.

Chancey, C., Griney, A., Volkova, E. \& Rios, M. 2015. The global ecology and epidemiology of West Nile virus. BioMed. Research International 2015: 1-20.

Ching, C.Y., Casais, J., Bowen, E.T., Simpson, D.I., Platt, G.S., Way, H.J. \& Smith, C.E. 1970. Arbovirus infections in Sarawak: The isolation of Kunjin virus from mosquitoes of the Culex pseudovishnui group. Annals of Tropical Medicine \& Parasitology 64(3): 263-268.

Dahlin, C.R., Hughes, D.F., Meshaka Jr., W.E., Coleman, C. \& Henning, J.D. 2016. Wild snakes harbor West Nile virus. One Health 2: 136-138.

Dauphin, G. \& Zientara, S. 2007. West Nile virus: Recent trends in diagnosis and vaccine development. Vaccine 25(30): 5563-5576.

Dupraz, M., Toty, C., Devillers, E., Blanchon, T., Elguero, E., Vittecoq, M., Moutailler, S. \& McCoy, K.D. 2017. Population structure of the soft tick Ornithodoros marimatus and its associated infectious agents within a colony of its seabird host Larus michahellis. International Journal for Parasitology \& Wildlife 6(2): 122-130.

Elisa, P.R., Franscisco, L. \& Miguel, A.J.C. 2014. Experimental infections of wild birds with West Nile virus. Viruses 6(2): 752-781.

Elseginy, S.A., Massarotti, A., Nawwar, G.A., Amin, K.M. \& Brancale, A. 2014. Small molecule inhibitors of West Nile virus. Antiviral Chemistry \& Chemotheraphy 23(5): 179-187.

Hayes, E.B., Komar, N., Nasci, R.S., Montgomery, S.P., O’Leary, D.R. \& Campbell, G.J. 2005. Epidemiology and transmission dynamics of West Nile virus disease. Emerging Infectious Disease 11(8): 1167-1173.

Impoinvil, D.E., Baylis, M. \& Solomon, T. 2012. Japanese Encephalitis: On the one health agenda. In One Health: The Human-Animal Environment Interfaces in Emerging Infectious Disease. Current Topics in Microbiology and Immunology, edited by Mackenzie, J., Jeggo, M., Daszak, P. \& Richt, J. Berlin: Springer. Vol. 365. pp. 205-247.

Kalaiyarasu, S., Mishra, N., Khetan, R.K. \& Singh, V.P. 2016. Serological evidence of widespread West Nile virus and Japanese Encephalitis virus infection in native domestic ducks (Anas platyrhynchos var domesticus) in Kuttanad Region, Kerala, India. Comparative Immunology, Microbiology \& Infectious Disease 48: 61-68.

Kilpatrick, A.M. 2011. Globalization, land use, and the invasion of West Nile virus. Science 334(1599): 323-327.

Komar, N., Langevin, S., Hinten, S., Nemeth, N., Edwards, E., Hettler, D., Davis, B., Bowen, R. \& Bunning, M. 2003. Experimental infection of North American birds with the New York 1999 strain of West Nile virus. Emerging Infectious Disease 9(3): 311-322. 
Kumar, K., Arshad, S.S., Selvarajah, G.T., Jalila, A., Toung, O.P., Abba, Y., Yasmin, A.R., Bande, F., Sharma, R. \& Ong, B.L. 2018. Japanese encephalitis in Malaysia: An overview and timeline. Acta Tropica 185: 219-229.

Lan, D., Ji, W., Yu, D., Chu, J., Wang, C., Yang, Z. \& Hua, X. 2011. Serological evidence of West Nile virus in dogs and cats in China. Archives of Virology 156(5): 893-895.

Ledermann, J.P., Lorono-Pino, M.A., Ellis, C., Saxton-Shaw, K.D., Blitvich, B.J., Beaty, B.J., Bowen, R.A. \& Powers, A.M. 2011. Evaluation of widely used diagnostic tests to detect West Nile virus infections in horses previously infected with St. Louis encephalitis virus or dengue virus Type 2. Clinical and Vaccine Immunology 18: 580-587.

Li, Y., Kamara, F., Zhou, G., Puthiyakunnon, S., Li, C., Liu, Y., Zhou, Y., Yao, L., Yan, G. \& Chen, X.G. 2014. Urbanization increases Aedes albopictus larval habitats and accelerates mosquito development survivorship. PLoS Neglected Tropical Disease 8(11): e3301.

Lvov, D.K., Butenko, A.M. \& Gromashevsky, V.L. 2004. West Nile virus and other zoonotic viruses in Russia: Examples of emerging-reemerging situations. Archives Virology Supplementa 18: 85-96.

Lynne, M.W. 2016. The practice of clinical virology: Virus taxonomy. EC Bacteriology and Virology Research 2.1: 43-48.

Malan,A.K., Stipanovich, P.J., Martins, T.B.,Hill,H.R. \& Litwin, C.M. 2003. Detection of IgG and IgM to West Nile virus. Microbiology and Infectious Disease 119(4): 1-8.

Marfin, A.A. \& Gubler, D.J. 2001. West Nile encephalitis: An emerging disease in the United States. Clinical Infectious Disease 33(10): 1713-1719.

Marlina, S., Muhd Radzi, S.F., Lani, R., Sieng, K.C., Abdul Rahim, N.A., Hassan, H., Li-Yen, C., AbuBakar, S. \& Zandi, K. 2014. Seroprevalance screening for the West Nile virus in Malaysia's orang asli population. Parasites \& Vectors 7(597): 1-7.

Morales, M.A., Fabbri, C.M., Zunino, G.E., Kowalewski, M.M., Luppo, V.C., Enria, D.A., Levis, S.C. \& Calderon, G.E. 2017. Detection of the mosquito-borne Flaviviruses, West Nile, dengue, Saint Loius encephalitis, Ilheus, Bussuquara, and yellow fever in free-ranging black howlers (Alouatta caraya) of Northeastern Argentina. PLoS Neglected Tropical Disease 11(2): 1-13.

Murgue, B., Murri, S., Triki, H., Deubel, V. \& Zeller, H.G. 2001. West Nile in the Mediterranean basin: 1950-2000. Annals of the New York Academy of Sciences 951: 117-126.

Padgett, K.A., Reisen, W.K., Kahl-Purcell, N., Fang, Y., CahoonYoung, B., Carney, R., Anderson, N., Zucca, L., Woods, L., Husted, S. \& Kramer, V.L. 2007. West Nile virus infection in tree squirrels (Rodenta: Sciuridae) in California, 2004-2005. The American Journal of Tropical Medicine \& Hygiene 76(5): 810-813.

Paily, K.P., Chandhiran, K., Vanamail, P., Pradeep, K.N. \& Jambulingam, P. 2013. Efficacy of a mermithid nematode Romanomermis iyengari (Welch) (Nematoda: Mermithidae) in controlling tree hole-breeding mosquito Aedes albopictus (Skuse) (Diptera: Culicidae) in a rubber plantation area of Kerala, India. Parasitology Research 112(3): 1299-1304.

Pattan, S.R., Doghe, N.S., Nirmal, S.A., Bhawar, S.B., Dighe, S.B., Gaware, V.M. \& Hole, M.H. 2009. Japanese encephalitis disease: A review. Pharmacologyonline 2: 550-560.

Pesko, K.N. \& Ebel, G.D. 2012. West Nile virus population genetics and evolution. Infection, Genetic and Evolution 12(2): 181-190.
Petersen, L.R., Brault,A.C. \& Nasci, R.S. 2013. West Nile virus: Review of the literature. The Journal of the American Medical Association 310(3): 308-315.

Rais, M.N., Omar, A.R., Jalila, A. \& Mohammed, H.O. 2011. Prevalence of West Nile virus antibody in captive bird populations in selected areas in Selangor, Malaysia. In 6th Seminar on Veterinary Sciences. 11-14 January 2011; Faculty of Veterinary Medicine, Universiti Putra Malaysia. p. 127.

Reisen, W.K. 2013. Ecology of West Nile virus in North America. Viruses 5(9): 2079-2105.

Richards, E.E., Masuoka, P., Brett-Major, D., Smith, M., Klein, T.A., Kim, H.C., Anyamba, A. \& Grieco, J. 2010. The relationship between mosquito abundance and rice field density in the Republic of Korea. International Journal of Health Geographics 9(32): 1-10.

Richter, J., Tryfonos, C., Tourvas, A., Floridou, D., Paphitou, N.I. \& Christodoulou, C. 2017. Complete genome sequence of West Nile virus (WNV) from the first human case of neuroinvasive WNV infection in Cyprus. Genome Announcements 5(43): e01110- e01117.

Rizzoli, A., Bolzoni, L., Chadwick, E.A., Capelli, G., Montarsi, F., Grisenti, M., de la Puente, J.M., Munoz, J., Figuerola, J., Soriguer, R., Anfora, G., Luca, M.D. \& Rosa, R. 2015. Understanding West Nile virus ecology in Europe: Culex pipiens host feeding preference in a hotspot of virus emergence. Parasites \& Vectors 8(213): 1-13.

Roehrig, J.T., Nash, D., Maldin, B., Labowitz, A., Denise, A.M., Lanciotti, R.S.\& Campbell, G.L. 2003. Persistence of virusreactive serum immunoglobulin $\mathrm{M}$ antibody in confirmed West Nile virus encephalitis cases. Emerging Infectious Disease 9(3): 376-379.

Sambri, V.,Capobianchi, M. \& Charrel, R. 2013. West Nile virus in Europe. Clinical Microbiology and Infection 19: 699-704.

Sifa, A.H., Yasmin, A.R., Noraniza, M.A., Mohammed, H.O., Omar, A.R., Arshad, S.S., Jalila, A., Ain Najwa, M.Y., Ayuni, W.N. \& Siti Tasnim, M. 2018. Serological and molecular detection of West Nile virus in equines in Malaysia. 13th Proceedings of the Seminar on Veterinary Sciences. 20-22 February 2018; Faculty of Veterinary Medicine, Universiti Putra Malaysia. p. 120.

Steele, K.E., Linn, M.J., Schoepp, R.J., Komar, N., Geisbert, T.W., Manduca, R.M., Calle, P.P., Raphael, B.I., Clippinger, T.L., Larsen, T., Smith, J., Lanciotti, R.S., Panella, N.A. \& Mc Namara, T.S. 2000. Pathology of fatal West Nile virus infection in native and exotic birds during the 1999 outbreak in New York City, New York. Veterinary Pathology 37(3): 208-224.

Sumodan, P.K., Vargas, R.M., Pothikasiorn, J., Sumanrote, A., Robin, R.L. \& Dujardin, J.P. 2015. Rubber plantations in Thailand and their mosquito fauna. In Socio-Ecological Dimensions of Infectious Diseases in Southeast Asia, edited by Serge, M., Jean-Pierre, D., Lefait-Robin, R. \& Apiwathnasorn, C. Singapore: Springer Science Business Media. pp. 155-170.

Trevejo, R.T. \& Eidson, M. 2008. Zoonosis update: West Nile virus. Journal of the American Veterinary Medical Association 232(9): 1302-1309.

van der Meulan, K.M., Pensaert, M.B. \& Nauwynck, H.J. 2005. West Nile virus in the vertebrate world. Archives of Virology 150(4): 637-657.

Vazquez, A., Sanchez-Seco, M.P. \& Ruiz, S. 2010. Putative new lineage of West Nile virus, Spain. Emerging Infectious Disease 16(3): 549-552. 
Ward, M.P., Schuermann, J.A., Highfield, L.D. \& Murray, K.O. 2006. Characteristics of an outbreak of West Nile virus encephalomyelitis in a previously uninfected population of horses. Veterinary Microbiology 118(3-4): 255-259.

Weingartl, H.M., Drebot, M.A., Hubalek, Z., Halouzka, J., Andonova, M., Dibemardo, A., Cottam-Birt, C., Larence, J. \& Marszal, P. 2003. Comparison of assays for the detection of West Nile virus antibodies in chicken serum. Canadian Journal of Veterinary Research 67(2): 128-132.

Yan-Jang, S.H., Higgs, S., Kate, M.H. \& Dana, L.V. 2014. Flavivirus-mosquito interactions. Viruses 6(11): 4703-4730.

Zahouli, J.B.Z., Koudou, B.G., Muller, P., Malone, D., Tano, Y.\& Utzinger, J.2017. Effect land-use changes on the abundance, distribution, and host-seeking behavior of Aedes arbovirus vector in oil palm-dominated landscapes, southeastern Cote d'lvoire. PLOS ONE 12(12): e0189082.

Nur Ain Najwa Mohd Yuseri \& Nor Yasmin Abd. Rahaman* Department of Veterinary Laboratory Diagnostics

Faculty of Veterinary Medicine

Universiti Putra Malaysia

43400 UPM Serdang, Selangor Darul Ehsan

Malaysia

Siti Suri Arshad \& Abdul Rahman Omar

Department of Veterinary Pathology and Microbiology

Faculty of Veterinary Medicine

Universiti Putra Malaysia

43400 UPM Serdang, Selangor Darul Ehsan

Malaysia
Jalila Abu

Department of Veterinary Clinical Studies

Faculty of Veterinary Medicine

Universiti Putra Malaysia

43400 UPM Serdang, Selangor Darul Ehsan

Malaysia

Abdul Rahman Omar

Laboratory of Vaccines and Immunotherapeutic

Institute of Bioscience

Universiti Putra Malaysia

43400 UPM Serdang, Selangor Darul Ehsan

Malaysia

Hussni Omar Mohammed

College of Veterinary Medicine

Department of Population Medicine and Diagnostic Sciences

Cornell University, Ithaca

New York 14853

United States of America

*Corresponding author; email: noryasmin@upm.edu.my

Received: 23 June 2019

Accepted: 2 October 2019 